\title{
Allergy to Goat/Sheep's Milk with Good Tolerance to Cow's Milk but Not to Cow's Milk Cheese: Identification of 1-105 Peptide from $\kappa$-Casein as the Molecular Basis of Reactivity toward Cow's Milk Cheese for Two Patients
}

\author{
Marion Beaumesnil ${ }^{2}$, Sandra Denery-Papini ${ }^{1}$, Martine Drouet ${ }^{2}$ \\ and Jean-Charles Gaudin ${ }^{1}$ \\ ${ }^{1}$ UR 1268 Biopolymères Interactions Assemblages, INRA, Rue de la Géraudière, France \\ ${ }^{2} \mathrm{CHU}$ d'Angers, Unité Allergologie Générale et Pneumologie, France
}

Correspondence should be addressed to: Jean-Charles Gaudin; jean-charles.gaudin@nantes.inra.fr

Received 23 August 2013; Accepted 30 October 2013; Published 27 December 2013

Academic Editor: Rita Nocerino

Copyright (C) 2013 Marion Beaumesnil, Sandra Denery-Papini, Martine Drouet and Jean-Charles Gaudin. Distributed under Creative Commons CC-BY 3.0

\begin{abstract}
In Europe, a new population of patients developing anaphylaxis to goat's/sheep's milk associated to tolerance to cow's milk has recently appeared. Nevertheless, among these patients, some show allergic reactions to cow's milk cheeses but these reactions are less severe than those directed against goat's/sheep's milk. The objective of the study was to the molecular determinants of the reactivity of this category of patients toward goat's/sheep's milk and cow's milk cheese. Western blots with either monoclonal antibodies specific of each casein or patients sera were performed. We confirmed that goat caseins are the main allergen recognized by patients with goat's/sheep's milk anaphylaxis. Patients IgE recognized also strongly and mainly bovine $\kappa$-casein 1-105 peptide which is present in cow's milk cheese but not in cow's milk. This peptide is generated by cleavage of $\kappa$-casein by chymosin during cheese fabrication. The reactivity of patients with anaphylaxis to goat's/sheep's milk toward cow's milk cheese is due to the presence of an epitope in bovine $\kappa$ casein 1-105 peptide, epitope absent or not accessible in full-length bovine $\kappa$-casein.
\end{abstract}

Keywords: Goat, Milk, Cheese, Allergy, Casein.

Cite this Article as: Marion Beaumesnil, Sandra Denery-Papini, Martine Drouet and Jean-Charles Gaudin (2013), "Allergy to Goat/Sheep's Milk with Good Tolerance to Cow's Milk but Not to Cow's Milk Cheese: Identification of 1-105 Peptide from $\kappa$-Casein as the Molecular Basis of Reactivity toward Cow's Milk Cheese for Two Patients," Research in Immunology: An International Journal, Vol. 2013 (2013), Article ID 168397, DOI: $10.5171 / 2013.168397$ 


\section{Introduction}

Allergy to cow's milk (CM) protein is a major cause of food allergy in infants (Dubuisson et al., 2002). The large majority of patients with $\mathrm{CM}$ allergy (CMA) also react against goat and sheep's milks (G/SM) (Restani et al., 1999). This strong cross-reactivity can be explained by the high degree of sequence homology between the main G/SM and CM allergens: $\beta$ lactoglobulin (Bos d5); $\alpha$-lactalbumin (Bos $\mathrm{d} 4)$ and caseins ( $\alpha_{s 1}, \alpha_{s 2}, \beta$ and $\kappa$ ) (Bos d8) (Table 1). Nevertheless, in Europe, a new population of patients has emerged since the beginning of the 1990s. These patients show, most of the time, severe allergy reactions to $\mathrm{G} / \mathrm{SM}$ associated with tolerance to $\mathrm{CM}$ (Wüthrich et al., 1995; Umpiérrez et al., 1999; Lamblin et al., 2001; Attou et al., 2005; Martins et al., 2005; Ah-Leung et al., 2006; Viñas et al., 2012). Whereas CMA appears in the first months of life and in most of the cases disappears by the age of three, G/SM allergy appears later and is persistent (AhLeung et al., 2006). The role of caseins in this reactivity seems to be predominant as compared to that of $\beta$-lactoglobulin or $\alpha$ lactalbumin (Umpiérrez et al., 1999; AhLeung et al., 2006; Muñoz Martín et al., 2004; Viñas et al., 2012). This observation is not surprising because sequence homology between bovine $\beta$-lactoglobulin and $\alpha$ lactalbumin (Table 1) with goat/sheep's corresponding proteins is very high (95\%). Caseins sequences from cows and goats/sheep are more distant (85-92\%) and it is therefore likely that specific epitopes in goat/sheep's caseins are recognized by the patients with G/SM allergy (G/SMA) and tolerant to $\mathrm{CM}$, however these epitopes are still unknown. Since identity between goat and sheep caseins reach $95-99 \%$, caseins epitopes between goats and sheep are likely common between the two species. We report that the molecular basis of the reactivity to CM cheese of patients with severe G/SMA but tolerating CM is an epitope included in 1-105 peptide of bovine -casein but absent in the full-length protein.

Table 1: Identity of G/SM Major Allergens with their Bovine Corresponding Proteins (alignment given identity \% was done with ClustalW2 at EMBL-EBI, Cambridge, UK)

\begin{tabular}{|c|c|c|}
\hline Allergen & Goat & Sheep \\
\hline$\beta$-Lactoglobulin & $95 \%$ & $95 \%$ \\
\hline$\alpha$-Lactalbumin & $95 \%$ & $95 \%$ \\
\hline$\alpha_{\mathrm{S} 1}$-Casein & $88 \%$ & $88 \%$ \\
\hline$\alpha_{\mathrm{S} 2}$-Casein & $88 \%$ & $89 \%$ \\
\hline$\beta$-Casein & $89 \%$ & $92 \%$ \\
\hline א-Casein & $85 \%$ & $85 \%$ \\
\hline
\end{tabular}

\section{Material and Methods}

\section{Patients}

Patient \#816, born in 1991, presented several anaphylactic reactions after ingesting diverse cheeses. The most severe shock arose with the goat cheeses and the last one, occurring in 2008, required 4 injections of adrenalin. CM cheeses also caused symptoms but less severe, ranging from oral syndrome to asthmatic dyspnoea. The most severe reaction (asthma) with $\mathrm{CM}$ cheeses arose after the ingestion of Raclette (melted cow's cheese of Swiss origin). As a child, he was never diagnosed allergic to $\mathrm{CM}$. The tests are positive for GM (SPT: weal of $6 \mathrm{~mm}$; IgE > $100 \mathrm{kUA} . \mathrm{L}^{-1}$ in 2008) and for CM (SPT: weal of $3 \mathrm{~mm}$, IgE 3.24 kUA.L-1 in 2008) (Table 2). Cutaneous tests for cheeses are strongly positive for Roquefort (sheep's milk cheese) with a weal of $15 \mathrm{~mm}$ but also for CM cheeses such as Camembert (weal of $6 \mathrm{~mm}$ ) and Raclette (weal of $10 \mathrm{~mm}$ ). 
Table 2: SPT and Specific IgE

\begin{tabular}{|c|c|c|c|c|c|c|c|c|c|c|c|}
\hline & & \multicolumn{2}{|c|}{ GM } & \multirow[b]{2}{*}{ SPT } & \multirow[b]{2}{*}{ IgEs } & \multirow{2}{*}{$\begin{array}{c}\mathrm{CM} \\
\operatorname{IgEs} \alpha \\
\alpha \text {-La }\end{array}$} & \multirow[b]{2}{*}{$\begin{array}{l}\text { IgEs } \\
\beta \text {-Lg }\end{array}$} & \multirow[b]{2}{*}{$\begin{array}{l}\text { IgEs } \\
\text { Cas }\end{array}$} & \multicolumn{3}{|c|}{ Cheeses SPT } \\
\hline & & SPT & $\operatorname{Ig} E_{s}$ & & & & & & $\begin{array}{c}\text { Ro } \\
\text { (SM) }\end{array}$ & $\begin{array}{c}\mathrm{Ca} \\
(\mathrm{CM})\end{array}$ & $\begin{array}{c}\mathrm{Ra} \\
(\mathrm{CM})\end{array}$ \\
\hline$\# 820$ & 1999 & $10 / 35$ & $>100$ & $6 / 25$ & 7.7 & 7.7 & 7.7 & 7.7 & nd & nd & nd \\
\hline & 2009 & $8 / 35$ & 87 & $2 / 2$ & 1.9 & 0.6 & 0.25 & 3.07 & nd & nd & nd \\
\hline \#816 & 2008 & $6 / 40$ & $>100$ & $3 / 15$ & 3.24 & 0.71 & $<0.10$ & 5.6 & $15 / 60$ & $7 / 35$ & $10 / 15$ \\
\hline
\end{tabular}

SPT: skin prick test; specific-IgE $\left(\operatorname{IgE}_{\mathrm{s}}\right)$ in kUA.L ${ }^{-1}$; cow's milk (CM); goat's milk (GM); sheep's milk (SM); $\alpha$-lactalbumin ( $\alpha$-La); $\beta$ lactoglobulin ( $\beta$-Lg); total caseins (Cas); Roquefort (made with sheep's milk) (Ro), camembert (made with cow's milk) (Ca) and raclette (made with cow's milk) (Ra) cheeses.

Patient \#820, born in 1993, presented two anaphylactic reactions at the age of 4 and 7 , a few minutes after ingesting goat cheese. The two shocks were severe (urticaria, oedema of the face and acute asthma). As a child, he was never diagnosed allergic to $\mathrm{CM}$ although having presented an atopic dermatitis during his childhood (no testing was done). Nevertheless, since then, patient \#820 reports allergic symptoms with CM cheeses, particularly with cheese spreads. The presented symptoms ranged from oral syndrome to asthmatic dyspnoea. The tests are positive for the GM (SPT: weal of $10 \mathrm{~mm}$, IgE 87 kUA.L $L^{-1}$ in 2008) and for CM (PT: weal of $6 \mathrm{~mm}$ in 1999, negative in 2010, IgE 7.7 kUA.L ${ }^{-1}$ in 1999, 1.9 kUA.L $^{-1}$ in 2009) (Table 2). We did not do any SPT for suspected cheeses.

In these two cases, G/SMA is confirmed. For the reactions imputed to $\mathrm{CM}$ cheeses, the interpretation was more delicate and two hypotheses were likely and perhaps not isolated from each other: 1) contamination of CM by GM; or 2) allergy to CM revealed only in its presentation under different forms of cheeses.

Serum was collected in the Laboratory of Immunology and Allergy of the Angers University Hospital (CHU) (France). Its was used under the signed consent of the patient or parents and after approval by the internal Ethical Committee of the hospital. Total IgE and specific IgE assays were done with the ImmunoCap $₫$ system (Phadia AB, Uppalla, Sweden).

\section{Skin Prick Test}

Skin Prick Test (SPT) were realized with natural cow's milk, commercial extract of Goat milk (ALK, Hørsholm, Denmark) and natural cheeses. Prick tests with allergens are considered positive when the wheal is either equal or superior to $3 \mathrm{~mm}$ or equivalent to half of the wheal with histamine (positive control).

\section{Preparation of Milk and Cheese Extracts}

Goat caseins (GCN) and goat whey proteins (GW) were separated from goat's raw milk. Milk fat was removed after centrifugation at $5000 \mathrm{~g}$ for $30 \mathrm{~min}$ at $30^{\circ} \mathrm{C}$. Milk was diluted $1: 3$ in water and $\mathrm{pH}$ was adjusted at 4.6 with $1 \mathrm{~N} \mathrm{HCl}$. After $1 \mathrm{~h}$ at room temperature with agitation the solution was centrifuged for $10 \mathrm{~min} 8000$ g. Caseins contained in the pellet were resuspended in water at $\mathrm{pH} 7$ at room temperature. Both whey proteins contained in the supernatant and solubilized caseins were dialyzed against milli-Q water for $48 \mathrm{~h}$ at $4^{\circ} \mathrm{C}$ and lyophilized. They were dissolved in Milli-Q water just prior use at the appropriate concentration.

Cheeses ( $1 \mathrm{~g}$ ) were grated and suspended in $5 \mathrm{~mL}$ of $0.4 \mathrm{M}$ trisodium citrate buffer $\mathrm{pH} 8.3$. The suspensions were homogenized for 1 min in an ice bath using an Ultra-Turrax T25 (IKA-Labortechnik, Staufen, Germany). 
Cheese were goat's cheese (GC) and cow's cheese (CC).

\section{Western Blot}

In a first step, milk and cheese proteins were separated according to their relative mass (Mr) by $12 \%$ SDS-PAGE after reduction. Milk and homogenized cheese suspension (200 $\mathrm{mg} / \mathrm{mL}$ ) were diluted 1:10 in SDS-PAGE loading buffer $(60 \mathrm{mM}$ Tris- $\mathrm{HCl} \mathrm{pH} 6.8,2 \%$ $(\mathrm{w} / \mathrm{v})$ SDS, $10 \%(\mathrm{v} / \mathrm{v})$ glycérol, $0.025 \%(\mathrm{w} / \mathrm{v})$ bromophenol blue and $5 \% \quad(\mathrm{v} / \mathrm{v})$ ? mercaptoethanol and approximately $7.5 \mu \mathrm{g}$ of proteins were loaded on the gel. Molecular weight makers were LMW marker (GE Healthcare Bio-Sciences AB, Uppsala, Sweden) and Precision Plus Protein Standards (Biorad, Hercules, CA, USA).

After separation proteins were electrotransferred on nitrocellulose membrane (Biorad) for $1 \mathrm{~h}$ at $250 \mathrm{~mA}$ in a buffer containing 25mM Tris, $192 \mathrm{mM}$ glycine, 20\% $(\mathrm{v} / \mathrm{v})$ ethanol. Membrane were incubated with either monoclonal antibodies specific of each casein or with the serum of the patient. Anti-bovine casein monoclonal antibodies mAb567 anti-? 1 -casein (zone 149-166),

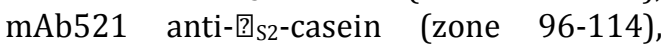
mAb657 anti-0?-casein (zone 133-150) and mAb257 anti-?-casein (zone 98-115) were a kind gift of Dr D. Dupont (INRA and Agrocampus, Rennes, France) (Johansson et al., 2009).

For staining with monoclonal antibodies, membranes were incubated for $1 \mathrm{~h}$ with a blocking solution of PBS (0.136 M NaCl, 2.68 $\mathrm{mM} \mathrm{KCl}, 1.46 \mathrm{mM} \mathrm{KH}_{2} \mathrm{PO}_{4}, 8.1 \mathrm{mM} \mathrm{Na}_{2} \mathrm{HPO}_{4}$, $\mathrm{pH} 7.4)$ containing $0.05 \%(\mathrm{v} / \mathrm{v})$ Tween-20 (PBS/T) and 4\% polyvinylpyrolidone (PVP) $(\mathrm{w} / \mathrm{v})$. After 2 washings for $10 \mathrm{~min}$ with PBS/T, membranes were incubated for $1 \mathrm{~h}$ with hybridoma supernatant containing the anti-casein monoclonal antibody. Membrane was washed as previously and incubated for $1 \mathrm{~h}$ at room temperature with an alkaline phosphatase-conjugated anti-mouse IgG (Sigma, St Quentin-Fallavier, France) diluted 1:3000 in PBS/T. The secondary antibody binding was revealed with the Immuno-Star AP kit (Biorad). Pictures were captured with a LAS-3000 imager (Fugifilm, Tokyo, Japan).

For patient's IgE detection, membranes were treated as describe above except that monoclonal antibodies were replaced by patient's serum diluted $1: 20$ in PBS/T containing 2\% (w/v) PVP. Bound IgE was revealed with an horse-radish peroxidaseconjugated anti-human IgE (DAKO, Trappes, France) diluted $1: 100,000$ in $\mathrm{PBS} / \mathrm{T}$ containing $2 \% \quad(\mathrm{w} / \mathrm{v})$ PVP by chemoluminescence (HRP Color Development kit, Biorad). Pictures were captured every $30 \mathrm{sec}$ with a LAS-3000 imager (Fugifilm, Tokyo, Japan) equipped with the appropriate filters.

\section{Results and Discussion}

CM, GM, CM cheese (line CC), GM cheese (line GC) as well as whole goat caseins (line GCN) and goat whey proteins (line GW) extracted from GM were submitted to SDS-PAGE. The gels were probed with antibodies specific for each bovine casein. The results show that all four antibodies are able to recognize goat caseins $\left(\alpha_{\mathrm{S} 1}, \alpha_{\mathrm{S} 2}, \beta\right.$ and $\left.\kappa\right)$ with good specificity (Fig. 1, see line GCN). In case of $\alpha_{S 1^{-}}$and $\beta$-caseins, many other bands are revealed. They correspond to degraded (hydrolyzed) forms of the proteins. In case of $\alpha_{s 2-}$ and $\kappa$-caseins only one band with lower molecular weight appears only in lines corresponding to cheeses. For $\kappa$-casein it can be attributed to peptide 1-105 obtained by cleavage of $\kappa$-casein by chymosin, a protease used in the fabrication of cheese. 


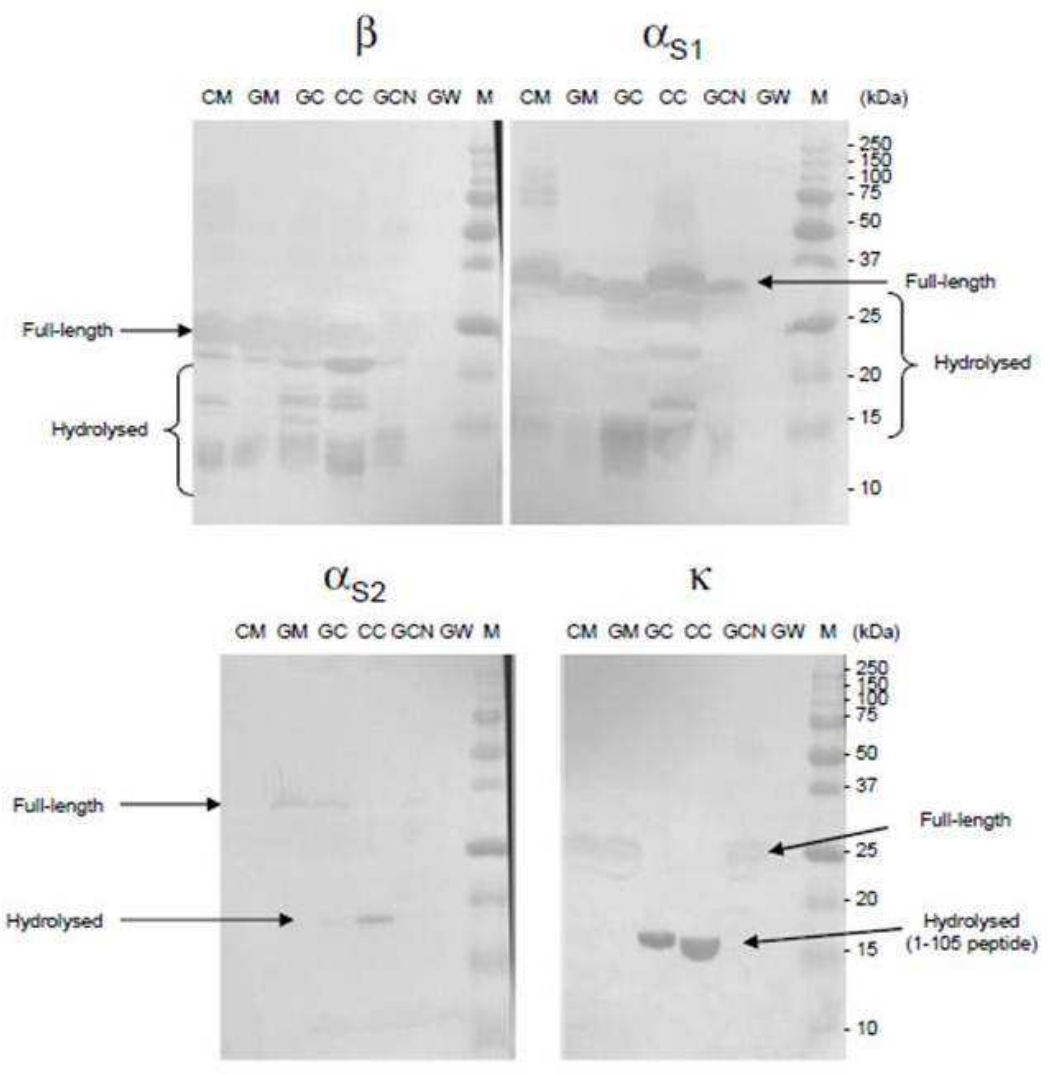

Figure 1: Western-Blot of Milk and Cheese Proteins Revealed with Caseins Specific Antibodies

Proteins from cow's milk (CM), goat's milk (GM), goat's cheese (GC), cow's cheese (CC), goat caseins (GCN) and goat whey (GW) were separated on $12 \%$ SDS-PAGE and blotted onto membranes. Membrane were incubated with monoclonal antibodies specific of each casein $(\alpha \mathrm{S} 1, \alpha \mathrm{S} 2, \beta$ and $\kappa)$. Bound antibodies were revealed by a colored method. M: molecular weight marker.

Both patient \#816 and \#820 have relatively similar clinical profiles: anaphylaxis to G/SM and G/SM cheese (several accidents); less severe allergic reactions to $\mathrm{CM}$ cheese and tolerance of $\mathrm{CM}$; both have high GM-specific $\operatorname{IgE}(>100 \mathrm{kUA} / \mathrm{L}$ and $87 \mathrm{kUA} / \mathrm{L}$ respectively) and low CM-specific IgE (3.24 kUA/L and 1.9 kUA/L respectively) (Table 2). Western-blot (Fig. 2) confirmed the strong reactivity of both patients toward goat caseins in milk, cheese and casein fraction (correspondence between bands detected by patients IgE (Fig.2) and by antibodies specific for each casein (Fig.1)). 

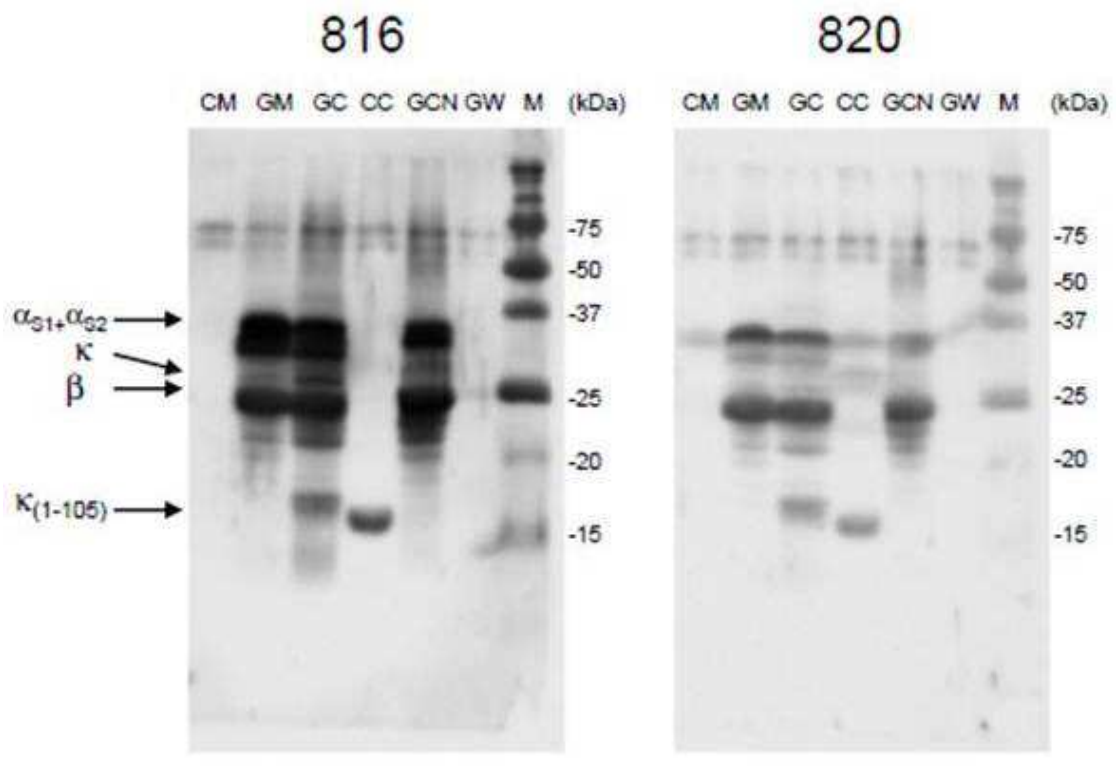

Figure 2: Western-Blot of Milk and Cheese Proteins Revealed with Serum from G/SMA Patients

Proteins from cow's milk (CM), goat's milk (GM), GM cheese (GC), CM cheese (CC), total goat caseins (GCN) and goat whey (GW) were separated on 12\% SDS-PAGE and blotted onto membranes. Membrane were incubated with the sera of two patients (\#816 and \#820) and bound IgE revealed by a chemoluminescence method. M: molecular weight marker.

No reactivity was found toward goat whey proteins (lines GW) (the two bands at $\mathrm{Mr}$ $\sim 65000$ and $\sim 70000$ are artifacts, they appear in every line even in case of totally negative serum). These results are consistent with previous observations (8). Patient 816 did not show any reactivity toward CM proteins and patient \#820 showed a very low reactivity toward bovine $\alpha_{\mathrm{s} \text {-caseins and their }}$ degraded forms in CM and cow's cheese. It is not possible to distinguish $\alpha_{\mathrm{S} 1-}$ from $\alpha_{\mathrm{S} 2}$ casein but reactivity is most likely directed against $\alpha_{S 1}$-casein which is much more abundant than $\alpha_{\mathrm{s} 2}$-casein. Surprisingly, both patients recognized strongly bovine $\kappa$-casein 1-105 peptide from CM cheese whereas they did not show any reactivity toward full- length bovine $\kappa$-casein (compare Fig.1 " $\kappa$ " and Fig. 2). A similar reactivity was also observed against $\kappa$-casein 1-105 peptide from GM cheese. It is likely that the intermediate reactivity of these patients against CM cheese is mainly due to the strong and specific recognition of this 1-105 $\kappa$ casein fragment which is generated during cheese fabrication. The cleavage of $\kappa$-casein by chymosin generates a strong immunogenic peptide and an immune reaction directed against an epitope which is not recognized in the full-length protein. Several hypothesis can be risen:1) the epitope is not accessible in the full-length protein; 2) a conformational epitope is generated because peptide 1-105 adopts a different conformation than full-length protein; 3) the epitope includes the Cterminal amino acid residues of 1-105 peptide and it is recognized only when the $\mathrm{COOH}$ of $\mathrm{Phe}_{105}$ is free (not included in peptide bond). This is a very uncommon situation in which proteolytic enzyme cleavage is able to generate a new strong immunogenic epitope. 


\section{Acknowledgement}

We thank Valérie Echasseriau for her excellent technical assistance.

\section{Abbreviations}

CMA: cow's milk allergy; CM: cow's milk; CG: goat's milk; G/SM: goat/sheep's milk; SM: sheep milk; G/SMA: goat/sheep's milk allergy; CC: cow's cheese; GC: goat's cheese; GW: goat whey proteins; GCN: goat caseins; Mr: relative mass, SPT: skin prick test.

\section{References}

Ah-Leung, S., Bernard, H., Bidat, E., Paty, E., Rancé, F., Scheinmann, P. \& Wal J.-M. (2006). "Allergy to Goat and Sheep Milk without Allergy to Cow's Milk," Allergy. 61 (11) 135865.

Attou, D., Caherec, A., Bensakhria, S., Dookna, P. \& Faverge, B. (2005). "Allergie aux Laits de Chèvre et de Brebis sans Allergie Associée au Lait de Vache : Revue Générale à Propos d'une Observation à Rebondissements," Revue Française d'Allergologie et d'Immunologie Clinique 45 601-07.

Dubuisson, C., La Vielle, S. \& Martin, A. (2002). Allergies Alimentaires: État des Lieux et Propositions, AFSAA (ed.). Agence Française de Sécurité Sanitaire des Aliments (report).

Johansson, A., Lugand, D., Rolet-Répécaud, 0. et al. (2009). "Epitope Characterization of a Supramolecular Protein Assembly with a Collection of Monoclonal Antibodies: The Case of Casein Micelle," Molecular Immunology 46 1058-66.

Lamblin, C., Bourrier, T., Orlando, J. P., Sauvage, C. \& Wallaert, B. (2001). "Allergie aux Laits de Chèvre et de Brebis sans Allergie Associée au Lait de Vache. Allergy to Goat's or Sheep's Milk without Allergy to Cow's Milk," Revue Française d'Allergologie et d'Immunologie Clinique 41 165-68.
Martins, P., Borrego, L. M., Pires, G., Pinto, P. L., Afonso, A. R. \& Rosado-Pinto, J. (2005). "Sheep and Goat's Milk Allergy - A Case Study," Allergy 60 (1) 129-30.

Muñoz Martín, T., de la Hoz Caballer, B., Marañón Lizana, F., González Mendiola, R., Prieto Montaño, P. \& Sánchez Cano, M. (2004). "Selective Allergy to Sheep's and Goat's Milk Proteins," Allergologia et Immunopathologia (Madr) 32 (1) 39-42.

Restani, P., Gaiaschi, A., Plebani, A., Beretta, B., Cavagni, G., Fiocchi, A., Poiesi, C., Velonà, T., Ugazio, A. G. \& Galli, C. L. (1999). "CrossReactivity between Milk Proteins from Different Animal Species," Clinical \& Experimental Allergy 29 (7) 997-1004.

Umpiérrez, A., Quirce, S., Marañón, F., Cuesta, J., García-Villamuza, Y., Lahoz, C. \& Sastre, J. (1999). "Allergy to Goat and Sheep Cheese with Good Tolerance to Cow Cheese," Clinical \& Experimental Allergy 29 (8) 1064-68.

Viñas, M., Carnés, J., López-Matas, M. A., Hernández, N., Castillo, M. J. \& Ibero, M. (2012). "Allergy to Goat and Sheep Cheese with Tolerance to Cow's Milk and its Derivatives," Allergologia et Immunopathologia (Madr) doi:pii: S03010546(12)00280-7.

Wüthrich, B. \& Johansson, S. G. O. (1995). "Allergy to Cheese Produced from Sheep's and Goat's Milk but not to Cheese Produced from Cow's Milk," Journal of Allergy and Clinical Immunology 